\title{
Micro-teaching in the Digital Industrial Era 4.0: Necessary or Not?
}

\author{
Eka Putri Azrai, Daniar Setyo Rini*, Ade Suryanda \\ Biology Education, Faculty of Mathematics and Science, Universitas Negeri Jakarta, Jakarta, Indonesia
}

Received September 7, 2019; Revised January 27, 2020; Accepted March 24, 2020

Copyright $\bigcirc 2020$ by authors, all rights reserved. Authors agree that this article remains permanently open access under the terms of the Creative Commons Attribution License 4.0 International License

\begin{abstract}
Background: The era of the industrial revolution 4.0 is often called the era of the digital revolution. In this era, the boundary line between biological, digital, and physical seems to fuse and become one so that it eventually becomes an era that has the characteristics of automation in all types of activities, the use of artificial intelligence in life, the use of machines and robots, the Internet of Things, networking and very open access to technology in life. Educators in the digital era are currently required to have 21st-century teaching skills to achieve the needs of superior generations in the digital age. Educational institutions of teaching professions are fully responsible for the fulfillment of teachers with the competencies needed in the current digital era. Micro-teaching is one of the teaching methods currently given to prospective teacher students to practice teaching skills in the classroom. However, the implementation of micro-teaching is considered to have many shortcomings including class conditioning that still seems unreal and lack of students' ability to design learning, especially in the current digital era. To answer this problem, researchers designed a series of studies to see what factors influenced the decline in performance. Aims: The focus of this research is conducted on micro-teaching learning methods that seem less effective in equipping teacher competencies, especially in the pedagogical and professional sections. This study aims to evaluate the implementation of micro-teaching, whether micro-teaching learning is still relevant to the digital era and to find out what factors are needed to fulfill the competencies of prospective teachers in the current digital era. Methods: A combination of quantitative and qualitative techniques was employed for the purpose of gathering the data. Mainly, a questionnaire and a focus group of discussions were used as the main tools for data collections. Result and conclusion: overall analysis of the findings indicated that the biggest obstacle in the implementation of micro-teaching is the lack of real experience regarding classroom conditions at school so that it still raises concerns in prospective teacher students. Prospective teachers described a variety of benefits they
\end{abstract}

gained from micro-teaching experiences. The study ended with recommendations and directions for future studies to further examine the highlighted result.

Keywords Micro-teaching, Pre-service Teacher, Evaluation, Revolution Industry Era 4.0

\section{Introduction}

The development of social life in society today has developed so rapidly. The industrial revolution that occurred had an enormous influence on the development of social life in all aspects of life as well as in the education' aspect. Industrial revolution 1.0 which focused on the development of the production of mechanical devices with steam technology shaped the social life of the people known as the "Hunting society" period. The industry continued to develop towards the revolution era 2.0, this period is known as "mass production and electricity" which developed the social life of agrarian societies. The development continued with electronic devices and IT technology and the entry of internet access into the 3.0 industrial revolution, this era developed the life of an industrial society which was marked by mass production of life necessities in a fast time.

In this 21st century, society has entered the next level, namely the 4.0 era and is ready to go into the 5.0 era. In the era of 4.0, society develops with advances in internet technology that build the environment of the cyber community or information society where it is easy for the public to gain access to information wherever and whenever. The era of the industrial revolution 4.0 is often called the era of the digital revolution. In this era, the boundary line between biological, digital, and physical seems to fuse and become one so that it eventually becomes an era that has the characteristics of automation in all types of activities, the use of artificial intelligence in life, the use of machines and robots, the Internet of Things, networking and very open 
access to technology in life. Educators in the digital era are currently required to have 21st-century teaching skills to achieve the needs of superior generations in the digital age.

The five main skills needed in the industrial revolution era 4.0 are digital, working with tools, technology, and computer skills, programming skills for robots and automation, and critical thinking. Other soft skills that need to be fulfilled by the world of education in the 21st century include the ability to read and write effectively, the ability to count, digital literacy, leadership, adaptability, ability to work together, communication skills, initiative, curiosity, the desire to continue learning, critical thinking and creativity. The world of education with students, teachers, and schools as the main actors requires special attention to meet the needs of the 21st century soft skills. Teachers as creators of the learning process in schools are certainly not only required to have the 21st-century skills but also competent to be able to apply these skills to be able to design learning that supports the current digital era. Answering this, an educator is required to be capable and competent in meeting the standard criteria of a good educator. Teacher competencies include pedagogical competencies, professional competencies, social competencies, and personal competencies with this digital era soft skills.

Teacher education in Indonesia is manage by Educational Personnel Education Institutions (EPEI) who has the responsibility to be able to create prospective teachers who meet the four competencies to become professional teachers. EPEI in Indonesia has done various things to produce professional teachers. One of them is by providing educational courses that are taught in stages following the stages of the learning process starting from the educational foundation to the practice of teaching skills (PTS). Micro-teaching is one of the teaching methods used by EPEI to provide teaching experience to prospective teacher students. This method was first coined by (1) someone who described that:

"micro-teaching is a teacher technique which allows teacher to apply clearly defining teaching skills to carefully prepared lessons in a planned series of five to ten minutes encountering with small group of real students, often with an opportunity to observe the result on videotape"

Micro-teaching is certainly widely used in educational institutions for teaching staff and also in public services or private companies engaged in training services (2). The micro-teaching method is very important in the application of theory in practice (2). Micro-teaching is a teaching technique for teaching staff designed by the School of Education at Stanford University and was first applied as a combination training and tool for diagnosing prospective educators at Stanford in 1963 (3). Micro-teaching designed by Stanford University has three main objectives, namely preliminary experience and practice in teaching, a research vehicle to explore training effects under controlled conditions and an in-service training instrument for experienced teacher (3). Micro-teaching is a method that aims to teach the behavior of a critical educator to a prospective educator. (2)

The results of several previous studies about micro-teaching said that micro-teaching did not consider very effectively in providing real experience to prospective teacher students (4). Micro-teaching in the process of implementation has undergone many modifications to make this method more real experiences for prospective teacher students. Motivated by the decline in teacher pedagogical competencies in Malaysia, a study was conducted and it was found that the "one by one" mentoring method was more effective in providing pedagogical competencies to prospective teachers students compared to micro-teaching (5). Another research said that mentoring "one by one" with one senior teacher in a school was more effective in providing an understanding of pedagogical competence for a prospective teacher (5). The research results above are supported by other studies which state that mentoring has a significant influence on improvingpedagogical competence (6).

Based on the evaluation research on the quality dynamics of prospective teacher students, the results show that the background of individual characteristics such as age, gender, and academic achievement index (GPA) values, provides the most significant relationship when compared to other factors such as teaching practice training (7). This opens up the idea that micro-teaching may be indeed ineffective as a method of training student teacher candidates with one of the biggest weaknesses being that it does not provide a real condition of the learning process. Considering that research on evaluating micro-teaching has also not been done for a very long time and has not been done much, it is deemed necessary to conduct research aimed at evaluating micro-teaching learning methods and providing innovations in this method to be able to adjust to the competency needs of teachers according to the times that have entered the digital era or often been called the industrial revolution era 4.0.

Universitas Negeri Jakarta is one of EPEI in Indonesia, in particular. The biology education study program found the same problem, namely the decline in the quality of student-teacher candidates in several pedagogical aspects. This can be seen from the student performance during practical teaching activities and also in preparing learning plans. To answer this problem, researchers designed a series of studies to see what factors influenced the decline in performance. At present, the focus of the research is on micro-teaching learning methods that seem less effective in equipping teacher competencies, especially in the pedagogical and professional sections. So it is necessary to hold an evaluation to find out what are the factors that hinder and support the implementation of micro-teaching.

\section{Methods}

This research is a mixed-method study with descriptive qualitative and quantitative approaches. The research was 
conducted at the Biology Education Study Program at UNJ in March, October 2019. This research is one part of the research into the development of micro-teaching instruments that are being developed as a whole. From a series of research activities covering 3 stages namely exploration and development, pilot studies and implementation, this research is included in the exploration phase which aims to evaluate the learning process of micro-teaching and its relation to find out what factors are influenced in the process. This exploration stage has several activities. First, literature review on the competencies that must be achieved by a prospective teacher in responding to the challenges of the industrial revolution in the field of education in the 21st century and its application in schools as an educational unit. Second, Focus Group Discussion (FGD) with students to find out their hopes and needs related to evaluating micro-teacing, standardized assessment instruments, competency of prospective teachers and providing good feedback so that they can reflect on prospective teachers. Third, distribution of learning evaluation questionnaires to students of 2015-2016 in the Biology Education Study Program, Universitas Negeri Jakarta.

A combination of quantitative and qualitative techniques was employed for the purpose of gathering the data. Mainly, a questionnaire and focus group discussions were used as the main tools for data collections. The questionnaire was developed to evaluate microteaching from the pre-service teacher' perceptions. The evaluation indicators adapted from Aelterman' research on development and evaluation of a training on need-supportive teaching in physical education, consist of three parts of the training in terms of interaction, innovation, interest, intelligibility, and essential (8). The questionnaire items to be rated on a 5-point Likert scale from 1 (strongly disagree) to 5 (strongly agree). The questionnaire were validated by experts and tested for reliability by Alpha cronbach with score 0.7 (high).

The research sample was active students of the biology education program, who had and/or were taking practical teaching skills courses (class of 2015-2016) as many as 65 people were taken with the Simple Random Sampling technique.The research data consists of two, namely: Quantitative data, taken using the learning process evaluation questionnaire with a total of 65 respondents. Qualitative data, taken using the focus group discussion method of 2 groups (@ 8-10 people) from class 2016 students who have taken the microteaching course and will be doing practical work practices at school as prospective teacher students.

Data analysis was carried out using an evaluation approach with a Kirkpatrick framework on several aspects. Quantitative data was analyzed with descriptive analysis and qualitative data was analyzed with thematic analysis
(9).

\section{Results and Discussions}

Retrieval of data in this study used a questionnaire evaluating the learning process and assessment of microteaching. Questionnaires were given to prospective teacher students with the criteria that students had followed the teaching skill practice (TSP) course. Students involved as respondents were students of Biology Education in 2015 and 2016 with a population of 115 people and the final number of samples obtained by the random sampling technique was 65 respondents (respond rate 57\%).

The characteristics of respondents showed that 65 respondents consist of 8 men (12.3\%) and 57 women (87.7\%). Respondents have ages in the range of $20-24$ years. Most of the ages are at 21 years old (60\%) and at least at 24 years old (1.5\%). As many as $98.5 \%$ of respondents have attended teaching practices and have experienced the process of implementing micro-teaching. In the micro-teaching course, several micro-teaching exercises were conducted, and $34.7 \%$ of respondents answered doing micro-teaching exercises 3 times and this was considered sufficient (75.4\%) to equip them before directly teaching the practice in school. Student GPA in the range $>3.50$ has the most amount which is $47.7 \%$. Details of the respondents' demographic table can be seen in table 1 . Based on the results of the questionnaire data a description of the data that can be seen in Figure 1 was obtained. The graph shows that students have a positive response regarding the evaluation of learning micro-teaching seen from green which is quite dominant in the graph. More than 30 respondents stated strongly that they agreed about teaching skill practice course learning and the micro-teaching method used has done well, sufficiently equipping them to practice directly teaching in schools, and making them understand about teacher competencies and teaching skills.

However, several things need to be analyzed in more depth, in the items of statements of confidence and the application of the theory obtained, it appears that many respondents also chose not to argue ( $\pm 19-24$ people). This indicates that there are still doubts and lack of confidence felt by students to teach directly at school. This is supported by several statements of students in focus group discussions (FGD) which state that there is still a lack of confidence, fear and worry about doing direct practice at school. Both stated directly or implicitly through a little smile expression and a long time lag to answer the question during the FGD activities. The statements that support student anxiety can be seen in the following quotes. 
Table 1. Demographic Data of Respondent Characteristics

\begin{tabular}{|c|c|c|c|}
\hline & & $\mathrm{n}$ & $\%$ \\
\hline \multirow[t]{2}{*}{ Gender } & Male & 8 & 12.3 \\
\hline & Female & 57 & 87.7 \\
\hline \multirow[t]{5}{*}{ GPA } & $<2.00$ & 2 & 3.1 \\
\hline & $2.00-2.75$ & 1 & 1.5 \\
\hline & $2.76-3.00$ & 2 & 3.1 \\
\hline & $3.00-3.50$ & 29 & 44.6 \\
\hline & $>3.50$ & 31 & 47.7 \\
\hline \multirow{2}{*}{$\begin{array}{l}\text { Have you taken or are currently taking a Teaching Skills Practice } \\
\text { course? }\end{array}$} & Yes & 64 & 98.5 \\
\hline & No & 1 & 1.5 \\
\hline \multirow{4}{*}{$\begin{array}{l}\text { How many times have you practiced in Teaching Skills Practice } \\
\text { lectures? }\end{array}$} & 1 & 4 & 6.2 \\
\hline & 2 & 5 & 4 \\
\hline & 3 & 43 & 34.7 \\
\hline & 4 & 13 & 10.5 \\
\hline \multirow{2}{*}{$\begin{array}{l}\text { Is the amount of practice you have done enough to make you } \\
\text { understand the eight teaching skills and be able to practice them? }\end{array}$} & Yes & 49 & 75.4 \\
\hline & No & 16 & 24.6 \\
\hline
\end{tabular}

"Because the teaching practice is only in the TSP course, (M1: the teaching practice is only in the PKM course) eh, maybe we are applying it, it still lacks experience, isn't it, mom" [FGD_PBB_A1]

17. Teaching Skill Practice (TSP) lectures went well

16. The educational courses that have been given specifically Teaching Skill Practice subjects are relevant and can be practiced in the classroom during practical activities at school.

15. Educational courses that have been given during lectures at the Study Program of Biology Education specifically in the TSP course provided me to be ready to become a teacher.

10. Teaching Skill Practice (TSP) courses help me meet the criteria to become a good teacher

9. After attending Teaching Skill Practice (TSP) courses, I am confident to go into the field and become a teacher

8.I confuse about applying the theory of teaching skills that have been obtained in the learning process in the classroom.

7. I understand about teacher competencies and teaching skills after attending Teaching Skill Practice (TSP) courses

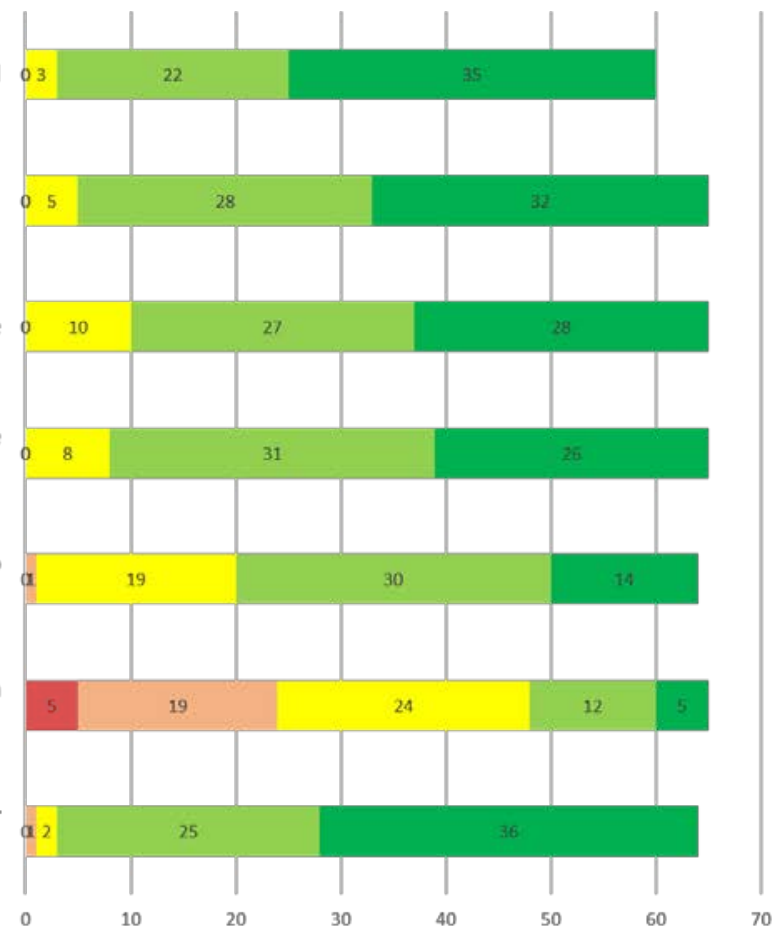

mStrongly disagree Disagree $\square$ Undecided Agree $\mathbf{m}$ Strongly Agree

Figure 1. Graphic Description of the Evaluation Questionnaire Results 
"Eee yeah [not sure] maybe in pre-service teaching course, we assume them as friends, ma'am, even though we consider him a student but his name is a friend, they certainly want to help us even though, if we ask they will certainly answer, it doesn't work, so life is like that but he lives eh, but when we were at school the students didn't know us that way, then they were very don't care about us, something like that, they didn't want to answer yes they didn't just want to answer like that, so what did they lack? We can do that while the course, but we are still afraid when we doing that in real school. (A3: not sure if it fits) when it fits in class (when it goes directly to the field) it seems like it will be different. Not as beautiful as this "[FGD_PBB_A1]"

"About after doing micro-teaching or practice in course do you feel confident or not to go to the field? Because of the 19th, it was already asked to be taken to school here. On the 15th there are even schools that have asked, are you confident or not? To be delivered to school. [not just an answer, grinning] not pretty sure, mom ... (hehe) [laughing] (I don't want to, ma'am) what should I do? Confidence? (what about my friends .... [laughter] [FGD_PBA_A6]

The statements and opinions of the students above prove that micro-teaching helps them in terms of training them to become a teacher. Because they are asked to be able to make learning plans in such a way in the allocation of time for 30 minutes. However, due to several factors at the time of the exercise of making their confidence decrease, one of them is because the condition of learning micro-teaching is not a real condition as they will face in school. So, then it causes anxiety and fear to face the real class situation. This appears in the statements of students during the FGD as follows.

"Eee yeah [not sure] maybe in pre-service teaching course, we assume them as friends, ma'am, even though we consider him a student but his name is a friend, they certainly want to help us even though, if we ask they will certainly answer, it doesn't work, so life is like that but he lives eh, but when we were at school the students didn't know us that way, then they don't care about us, something like that, they didn't want to answer yes, they didn't just want to answer like that, so what did they lack? We can do that while the course, but we are still afraid when we doing that in real school. (A3: not sure if it fits) when it fits in class (when it goes directly to the field) it seems like it will be different. Not as beautiful as this "[FGD_PBB_A1]"

"What do you want, the fear of meeting students is different, ma'am, (does that mean?) Like theories, in reality sometimes they are not the same" [FGD_PBB_A6]

"But you haven't gone to school yet, you don't know yet (that's why I'm not scared, we just suggest it, Mom, actually)" [FGD_PBB_A3]

Some of research states that micro-teaching has shortcomings in terms of providing real experience to prospective teacher students (4). The mistakes in the minicourse which uses expert models together with student teacher candidates, indicate that the expert models do not represent a lot of real conditions maybe because they are too standard or too perfect so that conflict conditions that often arise in the classroom cannot be experienced by student teacher candidates (4). Other research also supports the results of Cornford's research by stating that micro-teaching conducted by prospective teacher-students is nothing more than performing to complete assignments in a course so that it does not look like actual teaching (10). That research argues that although lecturers design micro-teaching learning as real as possible like conditioning student teacher candidates to dress like the teacher in the classroom or conditioning the class as in school, in fact, it still does not like its original condition. Sometimes student teacher candidates cannot answer questions raised by students only when students come from outside (not their friends) (10).

Overall, based on the respondents' opinions, micro-teaching is still needed and helps them to practice becoming a teacher. This result was supported by several previous study. In 2005 there is a study examined the reflective output of 31 secondary education pre-service teachers during a second micro-teaching session and concluded that student teachers considered micro-teaching as a favorable and meaningful learning experience (11). Prospective teachers at Ankara's Middle East Technical University in Turkey establish that students emphasized their needs for more opportunities to practice teaching through micro-teaching application (12)(13). In an another study which investigated the perceptions of student teachers at Florida State University found that the students overwhelmingly expressed that the opportunity to apply in practice the pedagogic theories they learned was extremely beneficial (14).

Although in its implementation it is necessary to make some changes to make the micro-teaching class feel as real as the class at school. Because the teacher's practical skills component can be improved by giving students prospective teachers a long time to be in school, adapting to the school environment and getting them involved in school activities (15). Evaluation, change, and innovation in the implementation of micro-teaching at this time are needed not only because of the shortcomings and weaknesses of the methods that have been experienced but also because of the demands of the needs of teachers in the current 4.0 era. The teacher needed in the 4.0 era is not only someone who is intellectual and skilled in teaching but is also someone who has soft skills and 21st-century skills that are in line with the development of the current digitalization era.

The generation of students continues to develop along with the times, therefore teachers must continue to grow in line with the times. In the 4.0 era, there are currently five skills that must be possessed namely digital skills, working with tools, technology, and computer skills, programming skills for robots and automation, and critical thinking. The 
current competency needs of teachers include teachers expected to have comprehensive assessment skills, 21st-century competencies, the ability to present modules by the interests/talents/ passion of students and the ability to present innovative authentic learning.

Based on the results of a survey that has been conducted, prospective teacher-students are currently actually aware of the development of teacher competency needs in the 4.0 era. This is indicated by $97.4 \%$ of respondents who answered yes and $2.6 \%$ of respondents who answered no to states whether they knew the industrial revolution 4.0. Prospective teacher students also think that the curriculum currently given to them is considered to have equipped them to be able to meet the demands of the teacher's competence with a yes answer survey of $73.7 \%$.

Nevertheless, there needs to be a re-evaluation of how much the curriculum that has been given affects the increasing competency of prospective teacher students. Based on the survey results it was found that of the four teacher competencies in the 4.0 era at present, the ability to present modules in accordance with students' interests/talents/ passions and the ability to present innovative authentic learning are judged to have not been well-facilitated in the curriculum they have currently received (Figure 2 ). This is in line with the anxiety of prospective teacher students regarding their readiness in facing the learning process in class and their skills in making learning plans that are conveyed in the FGD as follows.

"I think it is , the subject of theory learning"

"Learning theory, eh eh" "That's right there are approaches, methods, and that's right ... well, it's like we still know how to do it now"

"Still confused huh ... to distinguish (yes) in terms of concept? (yes) moreover to implement it (yes ma'am) "[FGD_PBA1_A3_A8]

EPEI in Indonesia has done various things to produce professional teachers as explained earlier. One of them is by providing educational courses that are taught in stages following the stages of the learning process starting from the educational foundation to the practice of teaching skills (PTS) with micro-teaching as a learning method. Based on the data above, the implementation of micro-teaching can be more effective if it is supported by the completeness of the learning process from other supporting courses especially on learning material about making a lesson plan for the class. If one of the learning processes in one of the courses in the curriculum is not carried out properly it will affect the process of implementing micro-teaching. The implementation of micro-teaching helps prospective teacher students to be able to implement pedagogic and professional competencies that they have gained in the classroom (16). This case stressed that micro-teaching serves as a reinforcement to implement pedagogic and professional competencies that students have gained during the previous learning process. The ability to present innovative authentic learning has not been well-facilitated in the learning process that has been obtained so far (figure 2).

Prospective teacher students also considered that the skill of giving advanced questions was one of the teaching skills that were very difficult to apply. This can be seen in the quotes in the FGD as follows.

"Maybe in my opinion, oh, this basic question, later will be this follow-up question, but it turns out, when the students answer, then we are confused like that, isn't that what it means" [FGD_PBB_A3]

"Yes, but sometimes we continue to question (not according to expectations) the students' answers, but the follow-up answers are not what we think about," he said. "[FGD_PBB_A3]

"It seems like we are not ready yet, why is this answer?" [FGD_PBB_A9]

"Yeah, so it's like looking for mom, [laughter]" [FGD_PBB_A9]

Based on the statements in the FGD above, it appears that prospective teachers-students are still not flexible and creative to be able to manage classroom conditions during the learning process. They are not ready to face classroom conditions that are outside of the scenario they have planned before. It can be seen from the results of the next survey (Figure 3) which show three 21st century skills are judged to be very lacking namely foreign language skills, analytical thinking skills, and creativity. Authentic learning and advanced questioning skills are two things that relate to teaching skills in evaluating teaching situations and are flexible in building effective responses during classroom teaching activities (17). This skill can be obtained ideally by providing direct experience to prospective teacher students regarding activities in school and making ongoing observations at school. 


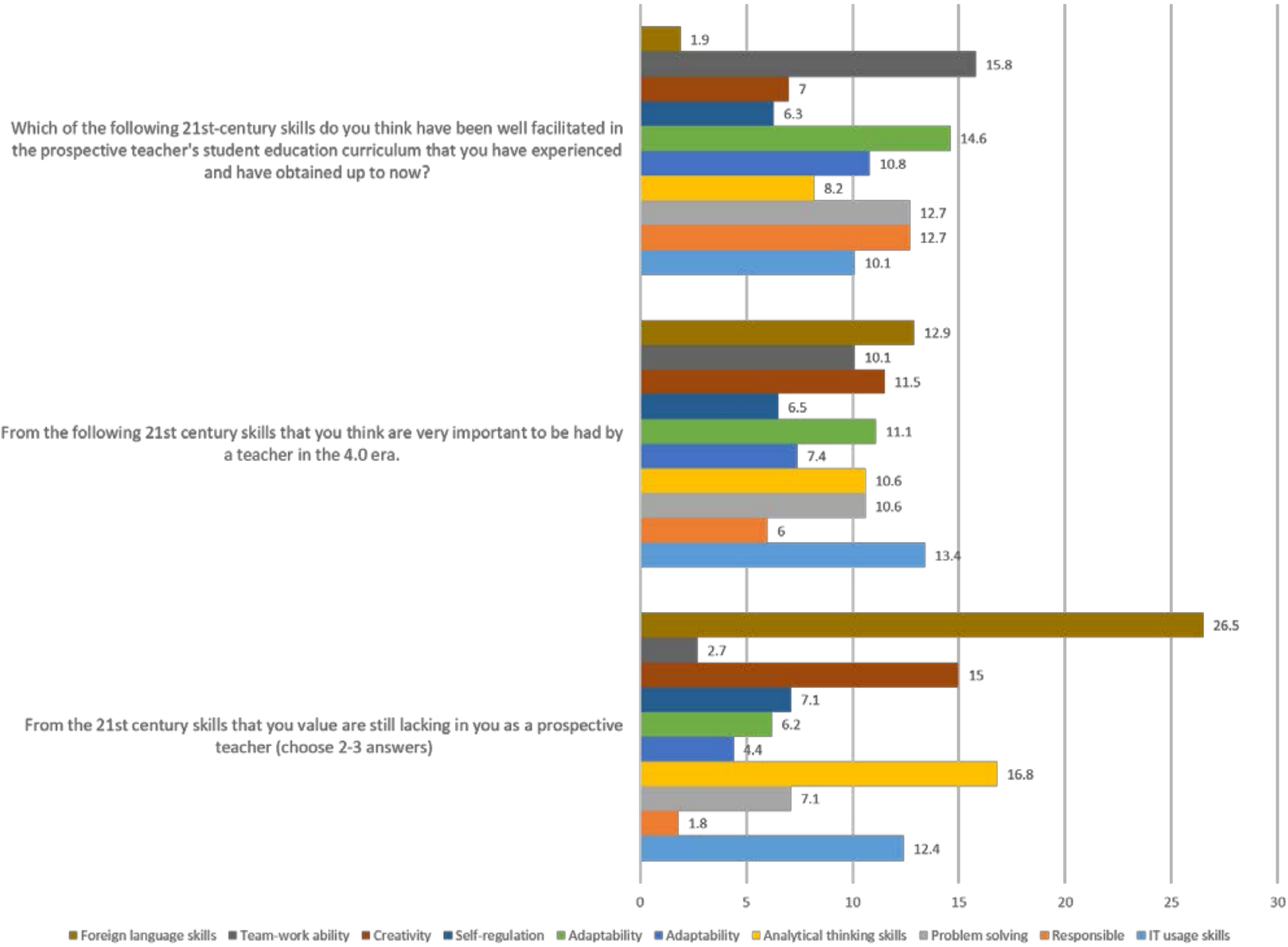

Figure 3. 21st Century Skills Survey for Teachers

However, this has become difficult to do so the problem at the moment is the separate experience of the prospective teacher's students regarding the theory gained from their practice. Snyder \& Darling-Hammond based on the results of their research stated that this ability can be trained using four learning strategies namely cases, exhibitions of performance, portfolio and problem-based inquiries (action research) (17-22). Cases can build the ability of prospective teacher students to make decisions. Exhibition of performances can help improve teaching performance and train student creativity. Portfolios support student teacher candidates to learn to reflect on themselves and action research can assist students in developing analytical thinking. As for the 10 skills of the 21st century that must be possessed, prospective teacher students assess the ability to work together / teamwork which is a skill that has been well facilitated (15.8\%).

Prospective teacher students in biology education study programs are indeed familiar with the process of cooperative learning that provides learning experiences in discussion activities to discuss a topic in groups. Apart from that, practicum activities in the laboratory or the field get them used to working in groups. Thus, the ability to work together is indeed very facilitated in the learning process of prospective teacher students in the biology education study program, UNJ. Foreign language skills and IT use skills are considered an important ability to be possessed by a teacher in the 4.0 era. Based on the results of the FGD, discussion, survey results and analysis that have been carried out solutions provided by respondents related to problems that have occurred so far regarding the implementation of micro-eaching and teacher competency needed in the 4.0 era are bring students from outside so that students are not friends themselves, doing the last exercise in school directly, shown a teaching video when giving initial material, giving feedback in the form of comments from lecturers and observers, providing examples of how to teach and apply biology learning material to students school later by lecturers, increasing activities and interactions with the school environment since the beginning of the semester, getting input and direct guidance from teachers who teach in schools, developing IT-based learning (E-learning), and providing learning experiences that practice effective communication skills, foreign language skills, and creativity. 


\section{Conclusions}

Micro-teaching is still needed to be carried out as a method of training prospective teacher students, although several things need to be changed and updated to suit the competency needs of teachers at present. Factors that need to be considered for updating the micro-teaching method include:classroom conditions that are made as real as possible with the conditions of the class at school (bringing students to practice directly at school during the last micro-teaching exercise), the use of standardized instruments to assist in providing comments when becoming an observer and can be used as a benchmark for designing learning in the classroom, giving feedback/comments is needed by students because feedback is a must in every microteaching, mentoring on by one by the original teacher who teaches at the school is something that needs to be considered so that students get a role model to be used as reference material, completeness of learning in the previous course becoming important in implementing better micro-teaching, provision of learning that emphasizes innovative authentic learning to support planning the learning process,developing IT-based learning (E-learning), and providing learning experiences that practice effective communication skills, foreign language skills, and creativity.

\section{REFERENCES}

[1] Macleod G. Microteaching: end of a research era? Int J Educ Res. 1987;11(5):531-41.

[2] Altuk YG, Kaya VH, Bahceci D. A Study on Developing "Microteaching Scale" for Student Teachers. Procedia - Soc Behav Sci. 2012;46:2964-9.

[3] Teacher I, Development S, Education T, Development B, Programs I, Teacher S, et al. Book- Micro-Teaching. 1966;(3).

[4] Cornford IR. Microteaching skill generalization and transfer: Training preservice teachers in introductory lesson skills. Teach Teach Educ. 1991;7(1):25-56.

[5] See NLM. Mentoring and Developing Pedagogical Content Knowledge in Beginning Teachers. Procedia - Soc Behav Sci [Internet]. 2014;123:53-62. Available from: http://dx.doi.org/10.1016/j.sbspro.2014.01.1397

[6] Mena J, Hennissen P, Loughran J. Developing pre-service teachers' professional knowledge of teaching: The influence of mentoring. Teach Teach Educ [Internet]. 2017;66:47-59. Available from: http://dx.doi.org/10.1016/j.tate.2017.03.024

[7] Vagi R, Pivovarova M, Barnard W. Dynamics of preservice teacher quality. Teach Teach Educ [Internet]. 2019;85:13-23. Available from: https://doi.org/10.1016/j.tate.2019.06.005

[8] Aelterman N, Vansteenkiste M, Van Keer H, De Meyer J,
Van den Berghe L, Haerens L. Development and evaluation of a training on need-supportive teaching in physical education: Qualitative and quantitative findings. Teach Teach Educ [Internet]. 2013;29(1):64-75. Available from: http://dx.doi.org/10.1016/j.tate.2012.09.001

[9] Kirkpatrick, DL; Kirkpatrick J. Evaluating Training Program. 3rd ed. German: Berret-Koehler Piblisher; 2006.

[10] Bell ND. Microteaching: What is it that is going on here? Linguist Educ. 2007;18(1):24-40.

[11] Amobi F., Irwin L. Implementing on-campus micro teaching to elicit pre-service teachers' reflection on teaching actions: Fresh perspective on an established practice. J Scholarsh Teach Learn. 2009;9(1):27-34.

[12] Saferoglu G. Teacher candidates' reflections on some components of a pre-service English teacher education program in Turkey. J Educ Teach. 2011;4(32):369-78.

[13] Ogeyik M. Attitudes of the students teachers in English language teaching programs towrds microteaching technique. English Lang Teach. 2009;3(2):205-12.

[14] Fernandez, ML; Robinson M. Prospective teachers' perspectives on microteaching lesson study. Education. 2007;2(127):203-15.

[15] Andreasen JK, Bjørndal CRP, Kovač VB. Being a teacher and teacher educator: The antecedents of teacher educator identity among mentor teachers. Teach Teach Educ. 2019;85.

[16] Bilen K. Effect of Micro Teaching Technique on Teacher Candidates' Beliefs regarding Mathematics Teaching. Procedia - Soc Behav Sci [Internet]. 2015;174:609-16. Available http://dx.doi.org/10.1016/j.sbspro.2015.01.590

[17] Snyder J, Darling-Hammond L. Authentic assessment of teaching in context. Teach Teach Educ. 2000;16:523-45.

[18] Miharja, F. J., Hindun, I., \&Fauzi, A. (2019). Critical thinking, metacognitive skills, and cognitive learning outcomes: a correlation study in genetic studies. Biosfer: Jurnal Pendidikan Biologi, 12(2), 135-143.

[19] Nurinayati, F., Sartono, N., \&Evriyani, D. (2014). Development of Digital Comic as Learning Media on Immune System Topic in SMAN 13 Jakarta. Biosfer: Jurnal Pendidikan Biologi, 7(2), 47-52.

[20] Suryanda, A., Rusdi, R., \&Kusumawati, D. (2017) PengembanganPraktikum Virtual UrinalisisSebagai Media PembelajaranBiologiSiswa SMA Kelas XI. Biosfer: Jurnal Pendidikan Biologi, 10(1), 1-8.

[21] Ristanto, R. H,.Miarsyah, M., Muharomah, D.R., Astuti, T.A., Aini, S., \&Prihatin., A.I (2019). Light-Board: simple media to learn photosynthesis concepts. International Journal of Advanced Trends in Computer Science and $\begin{array}{ll}\text { Engineering, } & 9(1),\end{array}$ https://doi.org/10.30534/ijatcse/2020/45912020

[22] Supriyatin, S., Rahayu, S., Ristanto, R. H., \&Ichsan, I. Z (2019). Improving HOTS in Biology Learning: A Supplement Book of Plant Growth and Development. Universal Journal of Educational Research, 7(12), 2642-2646.

[23] Seribulan, M. N. M., Rahayu, S., \&Isfaeni, H. (2014). Developing a Web-Based Learning (E-Learning) in General Biology Subjects with Joomla Program. Biosfer: Jurnal Pendidikan Biologi, 7(1), 1-9. 